\title{
Makna Material Culture dalam "Sarung" sebagai Identitas Santri
}

\author{
Toto Sugiarto \\ Pusat Studi Islam dan Kenegaraan (PSIK) Jakarta, Indonesia \\ email: totosugiarto@risindonews.com
}

\begin{abstract}
In material culture as a concept of local culture and nation heritage, "sarong" also has non-material value, likes as a symbol of santri, heroism, social class, kindness and honor. Sarong with variuos size, color, motifs, and pattern shapes the person and society, even the identity of a nation, especially Indonesia. Sarong even became part of the symbol of religiosity and diversity of Indonesia. By borrowing Bung Karno's message that the task of future generations is nation character building, caring for and developing a sarong culture, it can be seen as an effort to care for and develop the nation's character. Therefore, this paper use approachs or perspectives : material culture concept, social class perspective, and nation characer building concept. Method of writing is literary studies and analysis content method by various in resorches that support this article. The result of exprloration indicate that sarong can be the symbol for nation building character and identity with meaning and history contents powerly.
\end{abstract}

\section{Keyword:}

Sarong, Material Culture, Social Class, Nation Character Building

\begin{abstract}
Abstrak
Dalam budaya material (material culture) sebagai konsep budaya lokal dan warisan bangsa, "sarung" juga memiliki nilai non-material, seperti sebagai simbol santri, kepahlawanan (heroism), kelas sosial, kebaikan, dan kehormatan. Sarung dengan berbagai ukuran, warna, motif, dan pola membentuk orang dan masyarakat, bahkan identitas suatu bangsa, khususnya Indonesia. Sarung bahkan menjadi bagian dari simbol religiusitas dan keanekaragaman Indonesia. Dengan meminjam pesan Bung Karno bahwa tugas generasi mendatang adalah membangun karakter bangsa (nation character building), merawat dan mengembangkan budaya sarung, itu dapat dilihat sebagai upaya untuk merawat dan mengembangkan karakter bangsa. Oleh karena itu, makalah ini menggunakan pendekatan atau perspektif: konsep Material Culture, perspektif kelas sosial, dan konsep Nation Character Building. Metode penulisan adalah studi literatur dan analisis isi dari berbagai sumber yang mendukung artikel ini. Hasil penelitian menunjukkan bahwa sarung dapat menjadi simbol untuk karakter dan identitas pembangunan bangsa dengan makna dan isi sejarah yang kuat.
\end{abstract}

\section{Kata Kunci:}

Sarung, Budaya Material, Kelas Sosial, Pembangunan Karakter Bangsa 


\section{Pendahuluan}

Sarung saat ini sering menjadi representasi kalangan nahdliyin. Sebagai kelakar, seorang nahdliyin tanpa sarung perlu dipertanyakan kenahdliyinannya. Karena itu, mereka sering disebut sebagai "kaum sarungan". Bagi mereka, sarung memang tak terpisahkan. Sarung bisa untuk shalat, mengaji, tapi bisa juga untuk jalan-jalan atau bahkan main sepak bola. Para santri di pesantren seringkali bermain bola tanpa melepas sarung yang dipakainya. Namun demikian, sarung bukan hanya milik nahdliyin atau kaum muslim saja. Sarung juga biasa dipakai oleh beberapa kaum nonmuslim di Indonesia.

Sarung, menurut Rustanta berasal dari kata"sarunge dikurung" (sarung). Artinya, sarung merupakan instruksi kehidupan, agar manusia mengedepankan rasa malu, tidak sombong, tidak arogan, apalagi sembrono. Dengan memakai sarung, diharapkan seseorang akan terjaga segala perilakunya, memiliki rasa malu dan selalu bersikap sopan-santun. Di sini bisa dikatakan bahwa sarung memiliki makna yang tinggi. Lebih dari sekedar pakaian, sarung merupakan filosofi hidup. ${ }^{1}$

Sarung dapat didefinisikan sebagai kain lebar yang dijahit pada kedua ujunganya sehingga menyatu. Sarung dari sisi geografis pemakainya, dipakai juga oleh masyarakat di seluruh wilayah di Indonesia. Rakyat di daerah-daerah nonmuslim pun memproduksi sarung dan dipakai untuk kebutuhan acara adat dan kebutuhan sehari-hari. Masyarakat di Bali, Sumatera Utara, dan NTT pun kerap menggunakan sarung sebagai bagian dari pakaian adat. Berdasarkan hal tersebut, Clive Ganble menyebutkan bahwa sarung dapat dikatakan sebagai salah satu bagian dari objek material (material culture) bangsa Indonesia. Kebudayaan material atau objek material sendiri mengacu pada semua hasil kreasi manusia yang bersifat konkret. Selain itu, menurut Herdito Sandi Pratama, material culture juga dapat

\footnotetext{
${ }^{1}$ Agustinus Rustanta, Makana Simbol Busna Sarung Kyai Ma'ruf Amin, Jurnal Wima, Vol.8, No.2, 2019, 171
} 
dipahami sebagai suatu studi mengenai sistem nilai, keyakinan, gagasan, perilaku, dan asumsi sosial, melalui investigasi serius terhadap artefak. ${ }^{2}$

Namun demikian, sarung yang menurut sejarahnya terdapat perbedaan pendapat, ada yang mengatakan masuk ke Indonesia berasal dari Yaman dan ada yang mengatakan berasal dari Gujarat tersebut juga dipakai oleh banyak negara di Asia. Negara-negara tersebut antara lain India, Bangladesh, dan Thailand. Karena itu, jika ingin menjadikan sarung sebagai salah satu kekayaan kebudayaan material bangsa Indonesia, apalagi sebagai simbol nasionalisme, harus dicari sarung dengan karakter khas Indonesia. Untungnya, pencarian ini tidak sulit karena setiap sarung tradisional kita telah memilliki keunikan sendiri-sendiri.

Artikel ini mengupas tentang sarung sebagai bagian dari material culture dan industri budaya. Sebagai industri budaya, sarung dilihat dari proses produksi, pembuat, dan penggunanya. Sedangkan sarung sebagai material culture atau objek budaya, sarung di lihat dari sisi dimensi sosial dan makna yang melekat pada sarung tersebut. Selain itu, sarung juga memiliki nilai yang mendasar. Sarung sebagai identitas nasional atau bangsa adalah sarung sebagai material culture khas bangsa Indonesia yang membedakannnya dengan bangsa-bangsa lain. Selain itu, sarung juga menunjukan bahwa bangsa ini adalah bangsa yang religius.

Apa yang dimaksud identitas nasional atau bangsa? Tilaar dalam bukunya berjudul "MengIndonesia Etnisitas dan Identitas Bangsa" dalam Rifayanti , menjelaskan tentanng identitas nasional atau bangsa yang dikaitkan dengan identitas individu, dan identitas etnis ${ }^{3}$ sebagai berikut: Pertama, Identitas diri (self identity) merupakan komponen penting yang menunjukkan identitas personal individu. Semakin baik struktur pemahaman diri seseorang berkembang, semakin sadar individu akan keunikan dan kemiripan dengan orang lain, sebaliknya jika kurang

${ }^{2}$ Clive Gamble, The Basic Arkeology, New York: Routledge, 2004

\footnotetext{
${ }^{3}$ Tilaar dalam Rifayanti "MengIndonesia Etnisitas dan Identitas Bangsa", Jakarta: Rineka Cipta, $2007, .23$
} 
berkembang maka individu semakin tergantung pada sumber-sumber eksternal untuk evaluasi diri. Kedua, Identitas budaya (culture identity), mengacu keanggotaan formal atau informal dalam kelompok yang meneruskan dan menanamkan pengetahuan, keyakinan, nilai, sikap, tradisi dan cara hidup. Perhatian identitas budaya adalah mengenai apa yang telah dipelajari seseorang di masa lalu dan bagaimana mereka menggunakannya untuk mempengaruhi masa depan.Terakhir, Identitas nasional atau bangsa (nation identity) adalah suatu ciri yang dimiliki oleh suatu bangsa yang secara filosofis membedakan antara bangsa yang satu dengan bangsa yang lain.

\section{Tinjauan Pustaka}

Artikel ini menggunakan dua penelitian sebelumnya sebagai bahan acuan pustaka, sebagai berikut :

Pertama, yaitu dari jurnal yang ditulis Suryani Octavianingsih yang menjelaskan dari penelitiannya yang bermetode lapangan pada penduduk asli Bima dan kepustakaan tentang budaya warisan Rimpu (penutup kepala perempuan) yang terbuat dari kain yag ditenun tangan sebagai identitas budaya perempuan di komunitas Bima. Ada banyak cara rimpu: Rimpu Mpida (penutup terkecil), Rimpu Cili (penutup tersembunyi) dan Rimpu Colo (penutup kecil). Rimpu Mpida (penutup terkecil) biasanya dikenakan oleh perempuan yang belum menikah, sementara Rimpu Colo (penutup tipis) dipakai oleh perempuan yang sudah menikah. Studi ini menemukan bahwa banyak simbol dan makna Rimpu untuk perempuan yang belum menikah dan menikah dan mereka juga mewakili posisi, status dan peran dalam masyarakat. ${ }^{4}$

\footnotetext{
4 Suryani Octavianingsih, Rimpu: An Overview of Symbolic Meaning International Journal of Multicultural and Multireligious Understanding, Volume 6, Issue 3 April, 2019, . 614-621
} 
Sarung sebagai Material Culture yang Memperkuat Pancasila dan Bangsa Indonesia

Kedua, jurnal dari artikelnya Amang Fathurrohman ${ }^{5}$ yang mengangkat persoalan tentang kebijakan pemerintah pada pendidikan Islam di Indonesia antara Kemendikbud yang mendesentralisasi Kemenag karena dampak pemusatan pada kualitas, pelayanan, dan dukungan yang berbeda. Lembaga pendidikan Islam di bawah bidang Kemenag RI yang masing-masing wilayahnya memiliki pertumbuhan yang cepat, tapi pemerintah daerah cenderung tidak mendukung secara penuh pelayanan pendidikan Islam karena bukan kewajiban mereka. Kajian kualitatif dengan metode lapangan yang menggunakan pendekatan politik dalam perspektif institusional di Kabupaten Pasuruan Regency. Hasilnya menjelaskan bahwa Pemerintah di Pasuruan mengintegrasikan pendidikan pemerintahan dengan program baca-tulis sesuai dengan Al-Qur'an. Otonomi daerah Pasuruan menginisiasi kebijakan pendidikan "budaya menutup sarung" melalui pembentukan Kantor Cabang PERGURAG di bawah Kantor Pendidikan dan Budaya, sebagai bagian dari kebijakan tingkat lokal dalam rangka mendukung program Kemenag RI.

\section{Kerangka Teoretis}

Nonverbal Communication. Knapp menyebutkan beberapa jenis komunikasi nonverbal, diantaranya adalah komunikasi artefaktual. Komunikasi artefaktual berbicara tentang pesan nonverbal yang dikomunikasikan melalui penampilan atau cara berpakaian dan artefak-artefak lain seperti kosmetik, aksesoris yang digunakan, mobil, tata letak rumah atau barang. ${ }^{6}$ Barnard mengungkapkan bahwa pakaian adalah perlambangan jiwa kita. Pakaian berperan besar dalam menentukan citra seseorang. Pakaian yang dikenakan juga mencerminkan kepribadian seseorang apakah ia orang yang konservatif, religius, modern, atau berjiwa muda. ${ }^{7}$

\footnotetext{
${ }^{5}$ Amang Fathurrohman, Covert Sarong Culture Education Policy,DUCATIO : Journal of Education, Vol 4 No 1 (2019

${ }^{6}$ Mark.L. Knapp, Nonverbal Communication in Human Interaction. New York: Holt, Rinehart, and Winston, 1972

7 Barnard, (2011) dalam Dwi Retnani Srinarwati, Women As Imagery Consumer (Clothes And Cosmetics As The Phenomena Of Cultural Perspective Of Postmodernism), International Conference on Science, Technology and Humanity, 2015, 351
} 
Martial Culture. Gamble menyatakan material culture studies sebagai kebudayaan material atau objek material pada semua budaya atau kreativitas manusia yang bersifat real. Material culture bisa juga disebut sebagai suatu bidang kajian tentang sistem nilai, keyakinan, gagasan, perilaku, dan asumsi sosial, melalui investigasi serius terhadap artefak. ${ }^{8}$

Barthes menyatakan bahwa material culture adalah kebudayaan yang bisa dipahami melalui teks yang dapat dibaca dan dipahami maknanya. Di dalamnya terdapat sistem tanda yang memroduksi kebudayaan, dan sekaligus, kebudayaan memroduksi (dan mereproduksi) tanda-tanda. Dengan rangkaian logika inilah, Barthes memosisikan kebudayaan material setara dengan bahasa. Ia tertarik dengan praktik kultural sehari-hari. Menurutnya tidak ada satupun fakta ataupun kejadian yang murni dan transparan. Kebudayaan adalah ujaran dengan muatan pesan yang terkodifikasi dalam beragam bentuk. Untuk memahaminya diperlukan decoding. Dengan demikian, makna dari signifikasi menjadi koheren dengan siapa yang memroduksi dan mengonsumsi tanda-tanda.Singkatnya, kebudayaan adalah teks yang dapat dibaca dan dipahami maknanya. Di dalamnya terdapat sistem tanda yang memroduksi kebudayaan, dan sekaligus, kebudayaan memroduksi (dan mereproduksi) tanda-tanda. Dengan rangkaian logika inilah, Barthes memosisikan kebudayaan material setara dengan bahasa. Jika sebuah kebudayaan memroduksi produk-produk material yang secara arkeologis disebut artefak, maka artefak dengan sendirinya adalah tanda budaya. Budaya material dan artefaknya merupakan sistem tanda yang merepresentasikan dan membangun makna tertentu. Oleh karena kebudayaan material dan artefaknya memediasi relasi sosial dengan relasi produksi maka membaca sebuah artefak tidak hanya berarti membaca relasi kebendaan sebagai sebuah relasi dan produksi sosial, melainkan sebagai produk dari sistem signifikasi yang dibagi bersama secara kolektif. Individu dalam sebuah kebudayaan tidak menciptakan kebudayaan material. Ia dikonstruksi di dalam dan melalui kebudayaan

\footnotetext{
${ }^{8}$ Clive Gamble , The Basic Arkeology, 56
} 
materialnya. Dengan demikian, melalui emik dari relasi kebendaan sehari-hari, implikasi relasi kuasa dominan pada sebuah artefak dalam tataran etik dapat terungkap. ${ }^{9}$

Aspek ontologis dari sarung adalah perhatiannya pada budaya material artefak yang digunakan sebagai dasar dalam menafsirkan identitas sosial dan budaya manusia. Perkembangan ilmu pengetahuan manusia yang sedemikian cepat dan maju, mengehendaki ada upaya yang serius untuk mengevaluasi aspek ontologis dengan mendefinisikan kembali artefak, semisal sarung menjadi ilmu yang mempelajari identitas budaya dan karakter bangsa melalui budaya materialnya terlepas dari ruang dan waktu. Upaya redefinisi menjadi suatu tantangan untuk membangun udaya material modern dalam ilmu komunikasi nonverbal, khususnya artefaktual, yang direpresentasikan sarung .

Ihsan menyebutkan bahwa persoalan material culture studies yang sesungguhnya berakar dari ilmu arkelogi memang sangat perlu dikembangkan mengingat implementasinya yang stagnan dibandingkan ilmu-ilmu yang lain, namun masih memiliki harapan untuk dapat berkembang menuju perspektif material culture yang modern. ${ }^{10}$

Cultural Identity Theory. Hall seorang ahli komunikasi antar budaya menyatakan bahwa identitas budaya dapat diartikan sebagai berikut : Pertama, "The first position defines 'cultural identity' in terms of one, shared culture, a sort of collective 'one true self', hiding inside the many other, more superficial or artificially imposed 'selves', which people with a shared history and ancestry hold in common. ${ }^{11}$ Identitas di sini dilihat sebagai

\footnotetext{
${ }_{9}^{9}$ Roland Barthes, Mythologies. London: Paladin. 1973.

${ }^{10}$ Nur Ihsan D, Menera Ulang Kajian Kebudayaan Material Modern dalam Arkeologi, WalennaE : Journal of Research of South and Southeast Sulawesi, Vol. 11 No. 1, 2009, https://doi.org/10.24832/wln.v11i1, 205
}

${ }^{11}$ Stuart Hall, "Cultural Identity and Diaspora". In Patrick William dan Laura Chrisman (eds), Colonial Discourse and Postclonial Theory: A Reader. Harvester Wheatsheaf. 1993, 223 
sesuatu yang bersifat tetap. Budaya bersifat tetap dalam arti budaya bersama, jati diri kolektif. Identitas dalam dalam bentuk jati diri kolektif ini tidak berubah, kalaupun berubah, hal ini terjadi dalam jangka waktu yang amat lama, kira-kira akan terjadi dalam waktu beberapa generasi. Karena itu jati diri kolektif, meskipun dalam jangka waktu amat lama bisa saja berubah, namun dapat dikatakan sebagai being, sesuatu yang tetap.

Kedua, cultural identity, in this second sense, is a matter of 'becoming' as well as of 'being'. It belongs to the future as much as to the past. It is not something which already exists, transcending place, time, history and culture. Cultural identities come from somewhere, have histories. But, like everything which is historical, they undergo constant transformation. ${ }^{12}$ Identitas di sini dilihat sebagai sesuatu yang selalu berubah.

\section{Metode Penelitian}

Tulisan ini memakai metode penelitian kepustakaan (studi literature) pada karya dan tulisan-tulisa atau referensi yang memiliki konteks dan teori yang sama, yaitu material cultural, cultural idntity, character nation building, dan komunikasi nonverbal.

\section{Analisis dan Pembahasan}

Memakai sarung mengandung makna komunikasi nonverbal seperti yang disebutkan Knapp karena memiliki pesan yang tak terucapkan namun mampu untuk mendeskripsikan semua gejala dan kejadian komunikasi di se dunia. ${ }^{13}$ Sarung termasuk pada jenis komunikasi artefaktual, melalui objek-objek yang ada di sekeliling kita. Dengan mengenakan sarung, seseorang mengirim pesan berupa nilai, norma, dan simbol tertentu

\footnotetext{
${ }^{12}$ Stuart Hall, "Cultural Identity and Diaspora". In Patrick William dan Laura Chrisman (eds), Colonial Discourse and Postclonial Theory: A Reader, 225

${ }^{13}$ Mark.L. Knapp, Nonverbal Communication in Human Interaction, 102
} 


\section{Material Culture dan Sarung}

Material culture atau objek budaya erat kaitannya dengan bagaimana kita menjelaskan makna suatu benda, cara buat, bagaimana benda dipakai dan bagaimana benda dibuang, dan bagaimana perilaku orang terkait benda atau artefak tersebut. Material culture juga corncern tentang apa yang intangible dibalik yang tangible. Di sini diceritakan tentang makna sesuatu. Gayle Rubin ${ }^{14}$ misalnya menjelaskan dalam tulisannya terkait makna jaket kulit dan pemakainya. Jaket kulit tidak hanya bermakna pakaian yang menutupi tubuh, melainkan merupakan simbol. Dengan memakai jaket kulit, seseorang mengirimkan pesan akan suatu simbol tertentu pada dirinya.

Di sini material culture memiliki makna yang terdiri dari makna budaya atau makna simbolik. Material culture memiliki fungsi sosial. Suatu sarung yang berbahan halus dan bermerek juga sangat mahal, memiliki makna tertentu bagi pemakainya. Mereka kemudian mengkategorisasi diri sebagai "orang kaya". Zaman dahulu misalnya, terdapat kain tertentu yang hanya dipakai raja atau kalangan ningrat tertentu. Material culture bisa menjadi identitas diri. Saat ini, sarung merupakan identitas diri seorang santri.

Namun demikian, makna selalu berubah. Makna tidak pernah berhenti pada suatu titik atau kondisi. Kain yang zaman dulu hanya dipakai oleh raja atau kalangan ningrat tertentu misalnya, sekarang bisa dipakai semua orang, tidak hanya keturunan raja, asalkan ia memiliki uang untuk membelinya. Di sini makna kain tersebut berubah dari pakaian sebagai kelas sosial tertentu menjadi pakaian umum yang bisa dipakai semua orang.

\footnotetext{
${ }^{14}$ Gayle Rubin, Sites, Settlements, and Urban Sex: Archaeology And The Study of Gay Leathermen in San Francisco 1955-1995", in Robert Schmidt and Barbara Voss, eds., Archaeologies of Sexuality London: Routledge, 2000.
} 


\section{Identitas Kultural}

Sarung dapat menjadi objek studi material culture dalam arti bahwa melalui penelitian artefak atau objek material ini dapat dilakukan studi mengenai nilai, gagasan, perilaku, penanda sosial, religiusitas bahkan identitas bangsa. Sebagai identitas, sarung bisa dilihat sebagai being dan becoming sekaligus.

Terkait sarung sebagai being dan becoming ini, pemikiran Hall amat relevan. Identitas budaya menurutnya terbagi dalam dua arti, being dan becoming . Pertama, "The first position defines 'cultural identity' in terms of one, shared culture, a sort of collective 'one true self', hiding inside the many other, more superficial or artificially imposed 'selves', which people with a shared history and ancestry hold in common. ${ }^{15}$ Identitas di sini dilihat sebagai sesuatu yang bersifat tetap. Budaya bersifat tetap dalam arti budaya bersama, jati diri kolektif. Identitas dalam dalam bentuk jati diri kolektif ini tidak berubah, kalaupun berubah, hal ini terjadi dalam jangka waktu yang amat lama, kira-kira akan terjadi dalam waktu beberapa generasi. Karena itu jati diri kolektif, meskipun dalam jangka waktu amat lama bisa saja berubah, namun dapat dikatakan sebagai being, sesuatu yang tetap.

Kedua, "Cultural identity, in this second sense, is a matter of 'becoming' as well as of 'being'. It belongs to the future as much as to the past. It is not something which already exists, transcending place, time, history and culture. Cultural identities come from somewhere, have histories. But, like everything which is historical, they undergo constant transformation. Identitas di sini dilihat sebagai sesuatu yang selalu berubah.

Identitas tidak selalu dalam keadaan tetap. Perubahan akan semakin cepat jika ada pengaruh kuat dari luar. Identitas bangsa Indonesia sebagai masyarakat yang bersifat kolektifis misalnya, sekarang ini mulai terkikis akibat adanya pengaruh yang amat kuat dari budaya Barat. Budaya barat yang berciri individualistis sekarang ini mulai menjangkiti manusia Indonesia. Ciri khas bangsa yang kolektifis sekarang mulai luntur, berganti ciri sebagai masyarakat yang semakin individualis. Ciri

\footnotetext{
${ }^{15}$ Stuart Hall, "Cultural Identity and Diaspora". In Patrick William dan Laura Chrisman (eds), Colonial Discourse and Postclonial Theory: A Reader, 223
} 
individualis ini semakin lama semakin kental, mengalahkan ciri lama. Inilah contoh identitas yang becoming.

Sarung sebagai identitas kultural bisa dilihat dalam dua realitas tersebut. Keduanya mewakili masing-masing sebagai yang tetap (being) dan berubah/menjadi (becoming). Dalam hal sarung sebagai identitas kultural terdapat kesamaan dan kesinambungan identitas dengan masa lalu, berupa kesamaan ciri khas, karakter, dan lain-lain di masa lalu. Dalam sarung juga terdapat terdapat perubahan yang merupakan ketidak-sinambungan dengan masa lalu. Sarung ini selalu berkembang.

Identitas selalu terkait dengan masa lalu. Sebagai being, sarung adalah identitas sejak lama. Kehidupan masyarakat di Nusantara sudah mengenal sarung sejak beratus-ratus tahun lalu. Raja-raja di Bali sampai santri di pesantren-pesantren mengenakan sarung dalam berbagai aktivitas kehidupannya seperti pada upacara adat atau pada kehidupan sehari-hari. Sarung dilihat dari perspektif being ini, eksistensi sarung terlihat sepanjang masa. Inilah sarung dilihat dari sisi esensinya.

Sementara dilihat sebagai becoming, sarung terkait dengan masa kini dan masa depan. Sarung selalu mengalami perubahan. Sarung selalu dalam keadaan becoming. Sebagaimana bagian dari kebudayaan yang merupakan proses menjadi yang tidak pernah selesai, sarung bersifat dinamis mengikuti selera masyarakat. Identitas tidak pernah berhenti di satu titik. Identitas selalu mengalami perubahan mengikuti zaman. Inilah sarung dilihat dari penampilan luar yang dinamis mengikuti selera masyarakat konsumen.

Sebagai contoh sarung yang selalu dalam kondisi becoming (selalu dalam kondisi berubah), berikut ini perkembangan Sarung Tenun Ikat Donggala Kabupaten Donggala Provinsi Sulawesi Tengah tahun 2009-2013,16 sebagai berikut

${ }^{16}$ Asri Zeintatieni \& Inty Nahari, Sarung Tenun Ikat Donggala Kabupaten Donggala Provinsi Sulawesi Tengah, Tahun 2009, E-Journal. Volume 03 Nomor 01, Edisi Pebruari 2014, 46-58, 
1. Tahun 2009-2013. Bahan menggunakan benang sutra, katun, sintetis, serta campuran katun dan kapas, yang dikenal dengan nama "spunslik" atau yang lebih dikenal pengrajin dengan nama benang mesres.

2. Tahun 2009-2011. Motif yang digunakan adalah kain messa, sarung pelekat garusu dan buya cura, buya bomba, buya subi sabe, buya subi kumbaja, kombinasi buya bomba dan subi, buya bomba kota, serta buya awi. Tahun 2012-2013 motifnya sama dengan tahun sebelunya hanya buya subi sabe dan buya awi tidak digunakan lagi.

3. Tahun 2009-2011, ragam hias yang digunakan sama. Tahun 2012 ragam hias yang digunakan sama dengan tahun 2011, hanya tidak terdapat (punanu unu dan tonji kea) pada ragam hias utama, (bunga melati dan kuncup mawar) pada ragam hias isian, dan renda-renda pada ragam hias pinggiran. Tahun 2013 sama seperti tahun 2012, hanya pada ragam hias utama terdapat guma dan tidak terdapat (burung merak dan bunga lentera), ragam hias isian terdapat bunga cangkokan dan tidak terdapat (bunga anyelir, cempaka putih dan bunga lentera), ragam hias pinggiran terdapat segitiga.

4. Warna pada sarung tenun ikat terdiri dari warna terang dan warna gelap, selain itu tidak terdapat batasan warna pada sarung tenun ikat Donggala. Warna kuning dan ungu digemari konsumen ditahun 2010, warna orange menjadi tren ditahun 2012. Warna biru Benhur dan hijau zambrut merupakan tren warna ditahun 2013.

Sebagai artefak kebudayaan, sarung selalu mengalami perubahan, selalu dalam proses menjadi. Sarung merupakan contoh pembentukan identitas kultural yang terjadi dalam dunia yang terus mengalami perubahan. Dilihat dari penampilan luar ini, bisa dikatakan bahwa tidak ada yang abadi di dunia sarung, kecuali perubahan itu sendiri.

Para pengrajin sarung di berbagai daerah terus menciptakan kreasi baru. Namun demikian, setiap daerah memiliki ciri khas masing-masing. Ciri khas ini 
menjadi identitas kultural masing-masing daerah. saat ini kita mengenal banyak identitas sarung seperti sarung Ulos (Sumatera Utara), sarung tenun Goyor (Jawa Tengah), Sarung Tenun Poleng (Bali), sarung tenun Samarinda (Kalimantan Timur), dan sarung sutera Bugis (Sulawesi Selatan). Di samping sarung-sarung yang terkenal identitasnya tersebut, hampir setiap daerah di Indonesia memiliki sarung dengan ciri khas masing-masing. Sarung tenun Samarinda telah ditetapkan sebagai objek warisan budaya Indonesia dari Kalimantan Timur.

\section{Dimensi Sosial dan Politik: Makna Intangible}

Dilihat dari material culture ini, sarung juga, menandakan makna intangible berupa status sosial seseorang atau bermakna politik. Di sini sarung sebagai identitas diri atau penanda sosial bagi pemakainya. Sarung bisa bermakna sebagai penanda posisi, suatu kehormatan, atau posisi religious tertentu, bahkan bisa mengatur perilaku pemakainya. Namun demikian, tanda sebagai makna sosial bisa berubah sesuai konteks. Makna yang muncul di suatu zaman, bisa berubah pada zaman yang lain.

Dalam konteks perjuangan kemerdekaan, sarung memiliki makna intangible berupa nilai-nilai perjuangan bangsa. Sarung sering dipakai oleh pejuang dari kalangan tertentu. Di sini, sarung pernah menjadi simbol perlawanan terhadap penjajah. Sarung memiliki makna heroik. Di era penjajahan Belanda dan Jepang, tak sedikit kaum santri yang mengangkat senjata melawan penjajah. Dengan bambu runcing dan senjata tajam lainnya, mereka berperang. Banyak diantaranya tanpa melepas sarung sebagai identitas kesantriannya. Berperang dengan tetap bersarung menjadi identitas santri patriot dalam perjuangan memerdekakan bangsa dari cengkeraman kolonialisme dan imperialisme. Peran kaum sarungan ini amat besar dalam memerdekakan republik dari kekuasaan para penjajah. Sarung sebagai simbol anti-kolonialisme dan anti-imperialisme. 
Lainnya, sebagai material culture, sarung bisa mengubah kita, bagaimana kita berperilaku. Di sini, sarung bisa dipandang sebagai agen. Agen yang mengubah perilaku sosial. Things bisa menjadi agency. Sarung, selain ditentukan oleh kita, juga bisa menentukan kita, bisa mengatur perilaku kita. Sarung dilihat sebagai agen yang bisa mengubah atau menentukan perilaku sosial kita.

Sarung dikenal sebagai pakaian yang menunjukan kesopanan dan perilaku baik. Jika memakai sarung, seseorang akan berperilaku sebagaimana seharusnya jika memakai sarung, yaitu sopan, berperilaku baik, dan terhormat. Seseorang misalnya, jika memakai sarung tidak mungkin masuk ke tempat-tempat yang dilihat buruk di mata masyarakat seperti diskotik, klub malam, dan lokalisasi pelacuran. Ia akan berusaha berada di tempat yang semestinya seseorang sarungan berada. Sarung mengatur atau menjaga perilaku seseorang.

Sarung juga memiliki makna intangible sebagai pakaian kehormatan. Sarung dan peci bisa menjadi pakaian kehormatan. Ia layak dipakai oleh orang terhormat dan di berbagai forum terhormat. Hal ini ditunjukan presiden Joko Widodo, dalam beberapa kesempatan resmi, pemimpin bangsa yang berasal dari kalangan nasionalis ini berpakaian sarung dan peci.

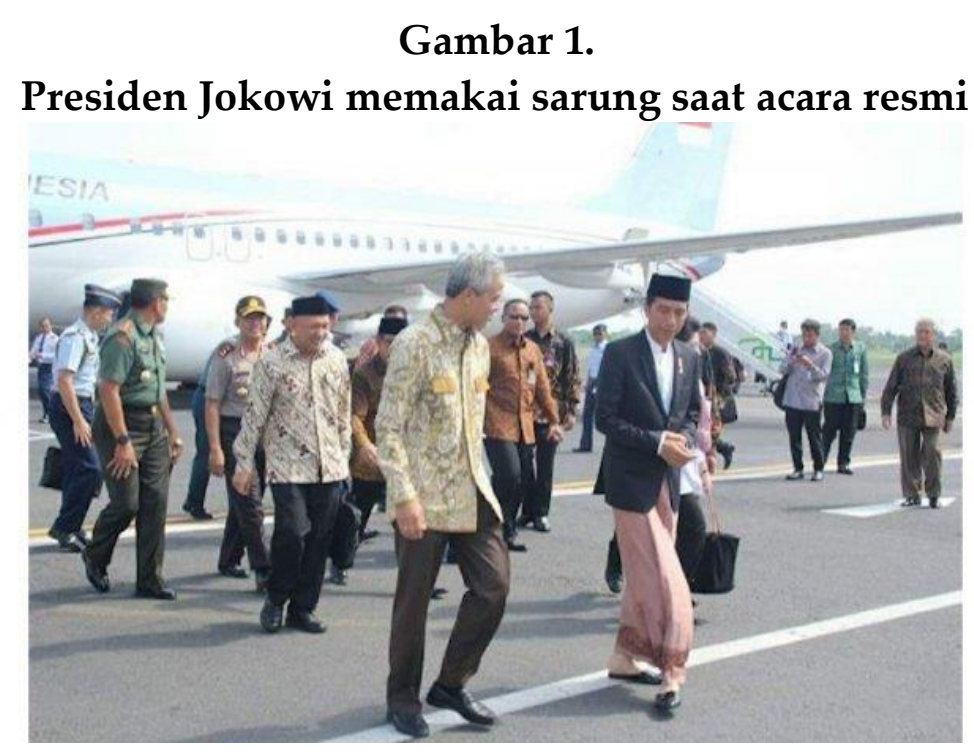

Sumber: Makassar.tribunnews.com

Selain sebagai kehormatan, sarung juga merupakan religiusitas. Pemakaian sarung sebagai ketaatan beragama terlihat pada sosok wakil presiden $\mathrm{KH}$ Ma'ruf 
Amin. Ma'ruf Amin, yang merupakan tokoh di kalangan nahdliyin ini, bahkan lebih konsisten dalam memakai sarung. Dalam setiap kesempatan, termasuk acara-acara formal, ia selalu memakai sarung. Identitasnya sebagai kyai dan tokoh NU selalu dijaganya dengan cara memakai sarung. Di sini, sarung merupakan religiusitas seseorang.

Pemakaian sarung oleh presiden dan wakil presiden tersebut tentu bukan tanpa tujuan. Mereka memakai sarung untuk mengkomunikasikan suatu pesan. Mereka tampak faham tentang hal ini di saat banyak orang lain tidak memahaminya. Inilah bentuk komunikasi artefaktual. Seperti dikatakan Pambayun bahwa dalam aktivitas komunikasi manusia seringkali melupakan yang substansi (hubungan antarmanusia) dan lebih mementingkan pengemasan isi pesan dan bagaimana menyampaikannya kepada pihak lain. Komunikasi nonverbal sebagai unsur pesan manusia yang vital, di mana lambang artifaktual di dalamnya juga menjadi salah satu penentu dalam mencapai keberhasilan proses komunikasi yang dilakukan. Dengan pemilihan pesan artifaktual yang tepat keberhasilan proses penyampaian pesan dalam komunikasi antarmanusia dapat dilaksanakan dengan lebih efektif untuk mencapai sasarannya. Bahkan secara nyata komunikasi artifaktual ini dapat dilakukan dengan tujuan memanipulasi pesan secara nonverbal yang akan memengaruhi komunikan agar mampu menerima, memahami bahkan melaksanakan isi pesan yang komunikator sampaikan. ${ }^{17}$

Sarung juga memiliki social life-nya sendiri. Karena berjalannya waktu, sarung bisa menjadi sarung lama. Sarung lama, pada suatu saat bisa dibuang atau disimpan pemiliknya karena merasa sudah lama atau bosan memakainya. Saat itu, sarung tersebut mungkin dilihat sebagai kain lusuh yang tidak lagi layak pakai dan tidak memiliki nilai ekonomi. Namun demikian, pada suatu saat di masa depan, sarung lusuh tersebut bisa berubah menjadi barang yang dinilai unik. Sarung ini kemudian

\footnotetext{
17 Pambayun, Ellys Lestari, Communication Quotient dalam Pendekatan Emosional dan Spiritual, Bandung: Rosdakarya, 2012, 327
} 
menjadi barang bernilai ekonomi yang sangat tinggi. Meminjam pemilahan nilai oleh Adam Smith yang memilah nilai menjadi nilai pakai atau nilai guna (value in use) $)^{18}$ dan nilai tukar (value in exchange) ${ }^{19}$, sarung ini memiliki nilai tukar tinggi. Nilai pakai dan nilai tukar, kata Adam Smith, seringkali tidak memiliki hubungan langsung. Sebagai contoh, jika dibandingkan antara air dan berlian, air tentu memiliki nilai pakai lebih tinggi dari berlian, namun berlian memiliki nilai tukar yang jauh lebih tinggi dari air. Begitu juga sarung, mungkin sudah tidak memiliki nilai pakai, karena akan mudah robek saat dipakai, namun sarung bisa saja memiliki nilai tukar yang amat tinggi. Dengan kata lain, sebagai barang bernilai, sarung lusuh ini mungkin sudah tidak memiliki nilai pakai, namun memiliki nilai tukar yang tinggi.

Sebagai bagian dari budaya dan perkembangannya, suatu kain sarung memiliki kemungkinan bisa menjadi barang yang memiliki nilai ekonomi tinggi di masa depan.

\section{Industri Budaya}

Perubahan semakin cepat dengan masuknya industri berteknologi modern dalam bidang sarung. Sekarang ini produksi sarung tidak hanya dikerjakan di rumah, berupa kerajinan rumahan, melainkan sebagai industri, bahkan dalam kategori industri besar. Banyak merek sarung sekarang ini merupakan merek-merek keluaran industri besar. Dengan adanya kemajuan teknologi, produksi sarung mengalami percepatan dari sisi kuantitas dengan perubahan gaya yang cepat pula. Sarung sebagai industri budaya terus mengalami perubahan sesuai selera zaman.

Kain lebar yang dijahit pada kedua ujunganya sehingga menyatu ini memiliki pasar yang luas di seluruh tanah air. Dengan pasar yang luas dan fanatik terhadap sarung, industri sarung berkembang dengan amat pesat dan berkecambah diberbagai tempat seperti di Jawa Timur, Jawa Tengah, Jawa Barat dan di luar Jawa. Berbegai merek, baik produk kerajinan ataupun industri mendapat kelasnya sendiri di masyarakat.

\footnotetext{
18 Agustiati, "Sistem Ekonomi Kapitalisme", Jurnal Academica, Vol. 1, No. 2, 2009, 152

${ }^{19}$ Agustiati, “Sistem Ekonomi Kapitalisme”, 154
} 
Dengan demikian, berdasarkan pembuatnya, sarung kemudian dapat dibedakan sebagai sarung buatan pabrik (besar, menengah, dan kecil) dan hasil kerajinan. Baik pada sarung buatan pabrik atau pun kerajinan rumahan terjadi komodifikasi. Mereka memiliki pasarnya sendiri sesuai harga dan kualitas. Untuk industri kecil dan rumahan, terdapat sentra produksi sarung, seperti di Majalaya, Jawa Barat. Sarung menjadi salah satu komoditi dalam industri budaya yang menguntungkan.

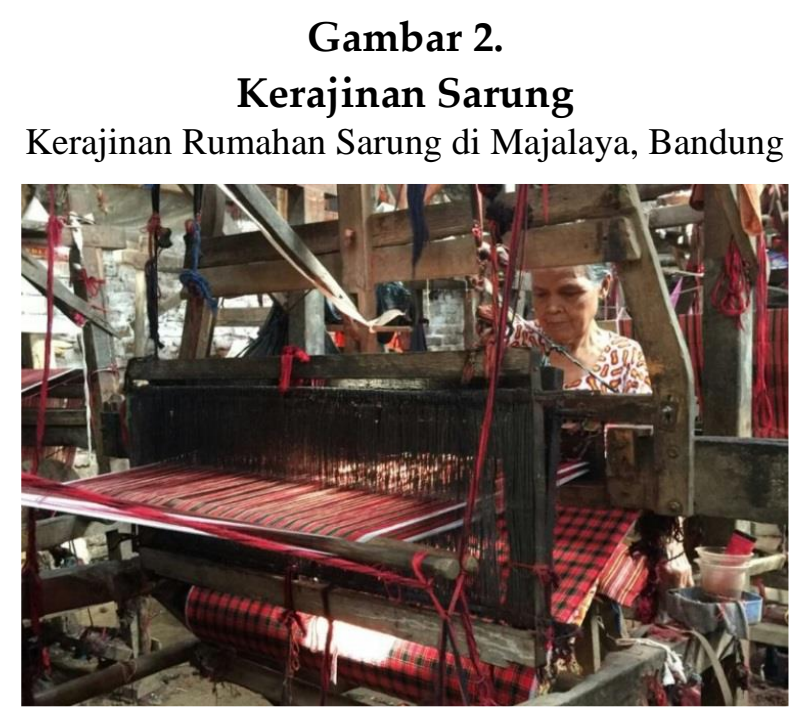

Foto: Kholid

Selain kerajinan dan industri kecil, terdapat pula banyak industri sarung berskala besar. Industri sarung skala besar ini menyasar semua kelas di masyarakat. Industri besar ini ada yang menyasar pasar kelas menengah ke atas. Ada pula yang menyasar pasar kelas menengah ke bawah. Perkembangan maraknya industri sarung dari skala kecil hingga besar ini positif. Identitas sarung sebagai material culture khas bangsa Indonesia ini semakin kuat.

Namun demikian, kadang terdapat hal negatif dari kontestasi bisnis, dan ini merupakan ciri khas kapitalisme, yaitu terpinggirkannya kerajinan rumahan dan industri kecil oleh industri besar. Pasalnya industri besar memiliki mesin-mesin baru yang jauh lebih canggih dan efisien, di samping mereka memiliki modal besar. Industri besar lebih efisien dan efektif. Dengan mesin yang mampu berproduksi secara cepat dan presisi, industry besar pada akhirnya mampu mendominasi pasar. 
Kapitalisme selalu diwarnai kontestasi keras. Dalam kapitalisme, hanya yang kuat yang akan memenangkan kontestasi. Dalam Bahasa Charles Darwin, survival of the fittest, hanya yang terkuat yang akan mampu bertahan. Teori inilah yang berlaku dalam industry sarung akhir-akhir ini. Persaingan keras dan cenderung kejam terjadi antar pemain sarung, mulai industry besar, sedang, sampai kecil dan industry rumah tangga. Di sinilah terlihat survival of the fittest-nya Charles Darwin berlaku. Industry mikro dan kecil terdesak oleh industri besar.

Seperti teori di atas, kerajinan dan industri rumahan sarung seperti di Majalaya tampak banyak yang mengalami kesulitan dalam mengembangkan usahanya. Mereka semakin terdesak oleh industri skala besar. Selain karena modal yang besar, industri skala besar ini juga efisien dalam operasi perusahaannya. Dengan mesinmesin yang baru (dibanding industri rumahan yang mesinnya manual dan rata-rata sudah tua seperti tampak pada gambar diatas), industri besar beroperasi lebih efektif dan efisien. Kondisi ini perlu menjadi perhatian pemerintah jika memang pemerintah masih peduli pada rakyat kecil. Pengusaha kecil perlu di dukung dalam hal kemampuan finansial dan keterampilan mengembangkan usaha.

Sementara berdasar model dan motifnya, kita mengenal sarung kotak-kotak, songket, batik, dan etnik. Setiap industri memiliki motif dan bahan andalan masingmasing. Terdapat pula industri yang memproduksi sarung berbagai motif untuk mendapatkan ceruk pasar yang lebih luas. Sarung kotak-kotak merupakan model yang paling banyak dijumpai. Model kotak-kotak pada sarung mengandung makna filosofi bahwa ketika kita berada di tengah-tengah, akan menjumpai perbedaan kemana pun kita melangkah, ke kiri, kanan, atas, dan bawah. Begitu pun hidup ini, selalu akan menjumpai perbedaan di sekitar kita.

Sarung etnik memiliki ciri khas yang lebih unik. Sarung tenun ikat Donggala misalnya memiliki motif dan ragam hias yang khas yaitu bunga, daun, fauna, serta unsur geometris, baik warna dan tehnik pembuatannya. Berbagai motif dan ragam hias terlihat begitu indahnya membuat sarung tenun ikat Donggala ini bernilai tinggi. 
Contoh keunikan lainnya ada pada sarung tenun Samarinda bahwa sarung yang merupakan hasil kebudayaan perempuan suku Bugis Wajo sudah ada sejak dahulu dan terus dilestarikan di Samarinda hingga sekarang memiliki berbagai corak. Setiap corak memiliki makna yang berbeda salah satunya corak pengantin yang dibawa oleh mempelai laki-laki sebagai syarat melamar. ${ }^{20}$

Sementara sarung Majalaya memiliki motif seperti motif poléng yang pernah popular di Majalaya tahun 1930-1970 dengan variasi poléng camat, poléng haji, poléng totog, poléng bolégbag, poléng taliktik, poléng namicalung. Motif poléng merupakan aplikasi dari motif dasar desain struktur yang termasuk kedalam kategori garis dan kotak-kotak. Kategori motif dasar desain struktur yang digunakan di Majalaya pada masa tersebut antara lain kategori desain kotak yang dibentuk dari garis benang, desain garis horisontal, desain kotak teratur, dan desain plaid. Octaviani dkk menyebutkan bahwa berbagai variasi poleng memiliki sejarah atau bentuknya sendiri-sendiri. Motif poleng camat merupakan motif yang popular di kalangan camat pada tahun 1930an. Poleng haji merupakan sarung dengan motif menyerupai kain ihram. Poleng totog merupakan sarung dengan motif khas seperti kain lurik. Poleng taliktik berbentuk motif kotak kecil-kecil. Sementara poleng balegbag berbentuk motif kotak besar-besar. Sementara poleng nammicalung merupakan motif yang banyak mendapat pengaruh dari sarung Samarinda. Namicalung sendiri, dikenal sebagai kampung tenun legendaris di Majalaya. ${ }^{21}$

Motif-motif dari berbagai daerah di atas menyimpan filosofi yang dalam terkait hidup dan kehidupan di tengah masyarakat. Berangkat dari berbagai filosofi itu, kita bisa mengambil pelajaran akan perlunya nilai-nilai toleransi dan solidaritas dalam kehidupan di masyarakat.

\footnotetext{
${ }^{20}$ Rifayanti, at al. "Filosofi Sarung Tenun Samarinda Sebagai Simbol dan Identitas Ibu Kota Kalimantan Timur", Psikostudia : Jurnal Psikologi, Vol.6 No.2, 2017, $26-27$.

${ }^{21}$ Octaviani , at al. Identifikasi Motif Lokal Sarung Majalaya Generasi Pertama, Arena Tekstil , Vol. 31 No. 2, 2016: 80-82.
} 
Dilihat dari cara pakainya, sarung ini biasanya dipakai dengan dililitkan. Sarung biasanya menutupi tubuh dari atas pinggang sampai di atas mata kaki. Namun demikian, sekarang ini banyak pihak seperti para desainer yang mengkreasikan sarung sebagai bagian dari pakaian (baju atau celana). Dalam pembuatan baju dan celana dari kain sarung ini berbagai motif seperti kotak-kotak, batik, dan etnik dipadukan. Kain sarung dalam bentuk baju dan celana ini tidak hanya diperuntukan bagi laki-laki, melainkan juga dipakai perempuan.

\section{Gambar 3.}

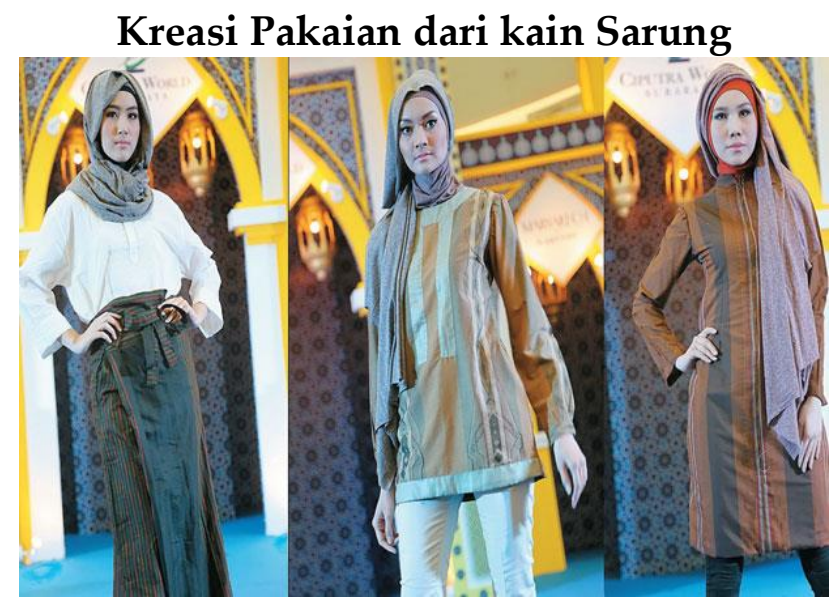

Sumber: https://daerah.sindonews.com

Dengan paduan motif dan warna yang serasi, pakaian dari kain sarung tampak menarik. Motif garis, kotak-kotak, batik, dan etnik dengan rata-rata warna kalem membuat pemakainya tampil elegan. Selain itu, kreativitas menampilkan sarung sebagai pakaian merupakan upaya untuk memperkuat identitas bangsa. Identitas bangsa kita yang beragam, tidak hanya manusianya, melainkan juga material culturenya, artefak-artefak yang melingkupi manusianya yang juga beragam. Sarung merupakan simbol keragaman bangsa.

\section{Gambar 4.}

Berbagai cara Memakai Sarung 


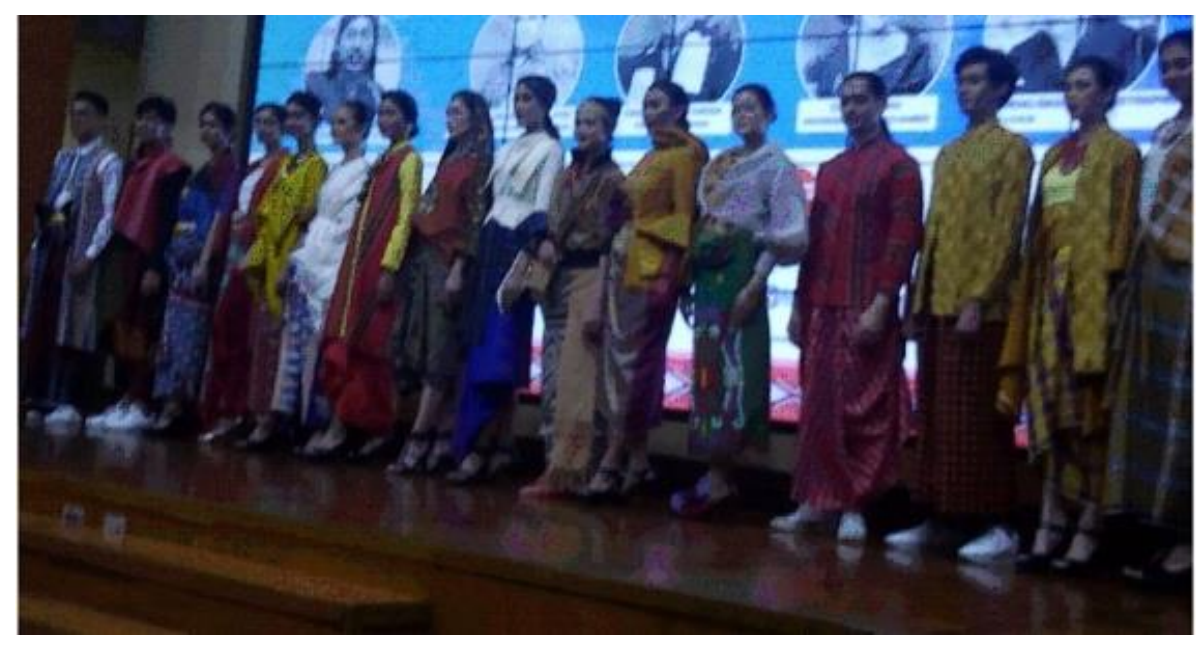

Sumber: Acara Festival Sarung Indonesia

\section{Kesimpulan}

Sarung sebagai objek material budaya dan media komunikasi non-verbal amat penuh dengan makna. Selain identitas kesantrian, sarung memiliki berbagai simbol seperti makna kepahlawanan (santri yang sedang berjuang melawan penjajah untuk merebut kemerdekaan), kelas sosial, kebaikan, kehormatan, dan keberagaman erat terpatri di dalam kain lebar yang dijahit sehingga menyatu pada kedua ujungnya ini. Dengan makna sejarah dan citra diri seperti itu, sarung semakin kuat mewarnai budaya bangsa Indonesia.

Secara identitas budaya, sarung ini pembeda dari budaya lain, pembeda dari budaya Arab misalnya. Di sini, berislam tidak perlu dengan menunjukan penampilan yang ke arab-araban. Sarung dapat menjadi pembeda dengan identitas lain dan menjadi ciri khas Nusantara. Sarung merupakan ciri khas budaya nusantara. Sarung yang ada di semua daerah, baik daerah mayoritas muslim atau pun non-muslim, juga simbol keberagaman, toleransi dan solidaritas. Di sini, sarung merupakan simbol identitas nasional.

Di sisi lain, sarung, baik buatan kerajinan rumahan, industri kecil dan besar, sama-sama menyimpan potensi ekonomi. Sarung merupakan bagian dari industri budaya yang menjanjikan. Apalagi jika bersinergis dengan kalangan fashion dan desainer, potensi sarung dapat lebih optimal. Cara pakai yang bisa dikreasikan sesuai 
keinginan membuat sarung merupakan objek budaya yang fleksibel disesuaikan dengan penampilan, baik untuk laki-laki ataupun perempuan. Hal ini membuat pasar sarung semakin luas. Sarung juga mampu berubah sesuai dinamika zaman.

Selain “diciptakan/ditentukan”, sarung juga "menciptakan/menentukan". Sarung dapat mempengaruhi pemakainya. Dalam hal ini sarung "menentukan/menciptakan" perilaku orang yang memakai benda atau artefak tersebut. Sarung adalah simbol kebaikan dan kehormatan bagi pemakainya. Sarungan bermakna menjaga tingkah laku, tidak sombong, dan tidak arogan. Karena itu sarung sebagai ciri khas bangsa Indonesia dapat juga turut menentukan karakter khas bangsa Indonesia, karakter yang baik dan terhormat.

Akhirnya, sebagai material culture, sarung memiliki nilai non-material. Nilai nonmaterial sarung seluruhnya baik, sebagai simbol kesantrian, kepahlawanan, kelas sosial, kebaikan, dan kehormatan, sarung membentuk pribadi dan masyarakat, bahkan suatu bangsa. Sarung bahkan menjadi bagian dari simbol religiusitas dan keberagaman bangsa Indonesia. Pada akhirnya, sarung turut menentukan perilaku individu pada suatu bangsa. Dengan merawat dan mengembangkan budaya sarung, berarti kita turut merawat dan membangun karakter bangsa sehingga pada akhirnya memperkuat dasar negara Pancasila dan eksistensi Bangsa Indonesia.

\section{Daftar Pustaka}

Agustiati, "Sistem Ekonomi Kapitalisme”, Jurnal Academica, Vol. 1, No. 2, 2009, 152

Agustinus Rustanta, Makana Simbol Busna Sarung Kyai Ma'ruf Amin, Jurnal Wima, Vol.8, No.2, 2019, 171

Amang Fathurrohman, Covert Sarong Culture Education Policy,DUCATIO : Journal of Education, Vol 4 No 1 (2019

Asri Zeintatieni \& Inty Nahari, Sarung Tenun Ikat Donggala Kabupaten Donggala Provinsi Sulawesi Tengah, Tahun 2009, E-Journal. Volume 03 Nomor 01, Edisi Pebruari 2014, 46-58, 
Barnard, (2011) dalam Dwi Retnani Srinarwati, Women As Imagery Consumer (Clothes And Cosmetics As The Phenomena Of Cultural Perspective Of Postmodernism), International Conference on Science, Technology and Humanity, 2015, 351

Clive Gamble, The Basic Arkeology, New York: Routledge, 2004

Gayle Rubin, Sites, Settlements, and Urban Sex: Archaeology And The Study of Gay Leathermen in San Francisco 1955-1995", in Robert Schmidt and Barbara Voss, eds., Archaeologies of Sexuality London: Routledge, 2000.

Mark.L. Knapp, Nonverbal Communication in Human Interaction. New York: Holt, Rinehart, and Winston, 1972

Nur Ihsan D, Menera Ulang Kajian Kebudayaan Material Modern dalam Arkeologi, WalennaE : Journal of Research of South and Southeast Sulawesi, Vol. 11 No. 1, 2009, https://doi.org/10.24832/wln.v11i1, 205

Octaviani , at al. Identifikasi Motif Lokal Sarung Majalaya Generasi Pertama, Arena Tekstil , Vol. 31 No. 2, 2016: 80-82.

Pambayun, Ellys Lestari, Communication Quotient dalam Pendekatan Emosional dan Spiritual, Bandung: Rosdakarya, 2012, 327

Rifayanti, at al. "Filosofi Sarung Tenun Samarinda Sebagai Simbol dan Identitas Ibu Kota Kalimantan Timur", Psikostudia : Jurnal Psikologi, Vol.6 No.2, 2017, 26-27. Roland Barthes, Mythologies. London: Paladin. 1973.

Stuart Hall, "Cultural Identity and Diaspora". In Patrick William dan Laura Chrisman (eds), Colonial Discourse and Postclonial Theory: A Reader. Harvester Wheatsheaf. 1993.

Suryani Octavianingsih, “Rimpu: An Overview of Symbolic Meaning”. International Journal of Multicultural and Multireligious Understanding, Volume 6, Issue 3 April, 2019, . 614-621

Tilaar dalam Rifayanti. Mengindonesia Etnisitas dan Identitas Bangsa. Jakarta: Rineka Cipta, 2007. 
Toto Sugiarto

100 | El Madani: Jurnal Dakwah dan Komunikasi Islam | Volume 2 No. 01 Tahun 2021, Hal. 77-100 